\title{
Ecosystem service trade-offs and land use among smallholder farmers in eastern Paraguay
}

\author{
Jake J. Grossman $^{1}$
}

\begin{abstract}
The trade-off between economically critical provisioning services and environmentally sustaining supporting services often seems absolute. Yet, when land use is inefficient, managers may be able to increase provision of both economically and ecologically sustaining services. To explore such sustainable "win-win" outcomes, I present a model of predicted trade-offs of provisioning and supporting services on smallholder farms in eastern Paraguay. The spatially implicit model simulates smallholder parcels as mosaics of subsistence agriculture, cattle pasture, eucalyptus plantations, and/or natural forest cover, and predicts provisioning and supporting service supply depending on the relative abundance of each land-use type per parcel. I represent provisioning services as the annual, per-ha proportion of a smallholder family's subsistence needs met by agriculture and forestry. I represent multidimensional supporting services as a composite index of forest bird biodiversity, soil organic carbon content, and aboveground annual net primary productivity (NPP) relative to what would be expected in a stand of high-quality Atlantic Forest. I use this model first to predict ecosystem-service supply for 38 actual smallholder parcels in rural eastern Paraguay, and then to generate an efficiency frontier that illustrates the optimal trade-offs between provisioning and supporting services that are biophysically possible for the system. Comparison of the empirical findings and the efficiency frontier indicates that current land use is inefficient relative to the biophysical optimum. All smallholder parcels included in the study but one lie far from the modeled efficiency frontier, indicating that for a given level of agricultural and forestry production, supporting services are not optimally conserved. If parcel owners were able to overcome constraints to sustainability by, for example, transitioning from cattle ranching to agroforestry production, they could protect high levels (often upward of $90 \%$ ) of the supporting ecosystem services provided by natural forest without sacrificing economically valuable provisioning services. Pathways to such sustainable outcomes are discussed.
\end{abstract}

Key Words: agroforestry; biodiversity; cash crops; efficiency frontier; eucalyptus; plantation forestry

\section{INTRODUCTION}

Attempts to foster sustainable land use in the Paraguayan Paraná Interior Atlantic Forest (Atlantic Forest) ecoregion take place against a backdrop of two juxtaposed social-ecological trends. The first is ongoing loss of forest cover and concomitant environmental degradation. Huang et al. (2007) report that roughly $50 \%$ of forest cover in the Atlantic Forest ecoregion was lost between 1973-2000. Only an estimated $12.9 \%$ of historical cover remains (Tabarelli 2010). Although the current national deforestation rate of $0.9 \%$ represents a reduction compared with historical levels (Hansen and DeFries 2004, Food and Agriculture Organization 2011), further losses will draw down an already diminished store of natural capital (Huang et al. 2009). Carlson and colleagues' (2011) scenario analysis of smallholder management of forested and previously forested lands in the region suggests that the perpetuation of current patterns of deforestation and agriculture could easily lead to deterioration of local environmental and economic conditions over the next 4050 yrs.

Unsustainable deforestation in the Paraguayan Atlantic Forest regrettably coincides with persistent economic pressure on regional smallholders. Extreme and overall poverty are disproportionately concentrated in Paraguay's rural communities (Berry 2010). Recent estimates indicate that $44.8 \%$ of the rural population lives below the poverty line as defined by the cost of goods and services required to satisfy basic needs (General Directorate for Statistics, Surveys and Census 2012). Agriculture -and especially the cultivation of "boom" crops (sensu Carter et al. 1996), like cotton and soy, for export-has historically been an important driver of national economic growth (Weisskoff 1992). Yet the benefits of agricultural development have largely accrued to a small portion of the population, while the rural poor have borne the lion's share of economic and environmental externalities. Rural poverty acts jointly with the intense economic pressure exerted by large soy, wheat, and cattle farmers to threaten remaining fragments of forested land in the Paraguayan Atlantic Forest (Macedo and Cartes 2003).

Encompassing portions of Paraguay, Argentina, and Brazil, the Atlantic Forest is a center of avian endemism (Goerck 1997, Fragano and Clay 2003, Cardoso da Silva et al. 2004) and the source of numerous ecosystem services for local and global populations (Silvano et al. 2005, Naidoo and Ricketts 2006). Although these services span the four classes defined in the Millennium Ecosystem Assessment (2005), the evaluation of two classes - provisioning and supporting services - is highlighted in this study of sustainable land-use decision making for the Atlantic Forest ecoregion. Provisioning services include all forms of biomass removal that provide people with food (e.g., soy, wheat, and cattle), fiber (e.g., cotton), and wood products (e.g., native hardwoods, eucalyptus, charcoal, and pulp). Supporting services are the ecological patterns and processes that facilitate and maintain provisioning, as well as regulating and cultural services. Important supporting services include nutrient cycling, soil formation, and primary productivity. Mace et al. (2012) note that biodiversity, by virtue of its well-documented role in driving ecological functionality and services (Hooper et al. 2005, Balvanera et al. 2006, Rey Benayas et al. 2009), can be considered as a prima facie ecosystem service or as a regulator of other services. In the present analysis, I will consider biodiversity as a supporting service, without which the supply and quality of other Atlantic Forest ecosystem services would be drastically reduced. 
As is the case globally (Geist and Lambin 2002), deforestation in the Atlantic Forest is driven both by large-scale commercial agriculture and ranching and by smallholder production (Cartes 2003, Food and Agriculture Organization 2004, Naidoo and Adamowicz 2006, Naidoo and Rickets 2006, Barona et al. 2010, Carlson et al. 2011). The land-use practices of smallholders are of special interest for several reasons. Although private ownership of land remains incredibly unequal, and the shrinking population of smallholders with legal land tenure faces persistent economic pressure from the expansion of large-scale landowners, smallholder production remains central to both local and national food economies (Quintana and Morse 2005, Hetherington 2009, Berry 2010, Vázquez-León 2010, Finnis et al. 2012). Additionally, smallholder land management can be more diverse, less inputintensive, and more attuned to local economic dynamics, allowing for greater retention of supporting services alongside provisioning services (International Assessment of Agricultural Knowledge, Science, and Technology for Development 2009, Galeano 2010, Perfecto and Vandermeer 2010, Tscharntke et al. 2012). Because large-scale soy farming and cattle ranching are often dependent on low-diversity, input-intensive practices and are tightly linked to global commodity markets, these systems generally maximize provisioning services, frequently resulting in environmental degradation (Lambin et al. 2001, Elgert 2012). Therefore, understanding smallholder land management is critical to sustainable development in rural eastern Paraguay and analogous regions elsewhere.

Smallholders' land-use options are not confined to forest preservation, traditional row cropping, and cattle ranching (Hamilton and Bliss 1998, Ministry of Agriculture and Livestock 2008, Carlson et al. 2011, Finnis et al. 2012). The last several decades have seen the promotion of a variety of alternative forest crops that meet subsistence needs for both food and wood while also generating commercial income. These tree crops include grafted citrus, yerba mate (Ilex Paraguariensis A. St. Hil.), and native and exotic forestry plantations. Eucalyptus (Eucalyptus L. 'Hér. spp.) plantations have become especially important in eastern Paraguay during the last twenty years (Ministry of Agriculture and Livestock 2009). Exotic eucalyptus is fastgrowing, hardy, and profitable (Ministry of Agriculture and Livestock 2008, Cubbage et al. 2010). However, eucalyptusplantation forestry is also associated with excessive drying of the soil and allelopathic harm to crops and natural vegetation, and may not meet smallholders' subsistence needs (Couto and Dube 2001, Doughty 2001, Cossalter and Pye-Smith 2003). As a result, eucalyptus-plantation forestry is controversial and has drawn criticism from some ecologists and development workers (Shiva and Bandyopadhyay 1987, Cossalter and Pye-Smith 2003). Yet the negative ecological impacts of eucalyptus are complex (Cuoto and Dube 2001, Rivzi et al. 2009, Grossman, personal observation), and eucalyptus forestry can be an economically viable source of provisioning, and perhaps supporting, ecosystem services (Brockerhoff et al. 2010, Ditt et al. 2010).

Landscapes are biophysically heterogeneous, and the suite of ecosystem services that a landscape provides for its human inhabitants reflects this heterogeneity. However, the relative types and quantities of these services are further modulated by individual and collective decisions about how to manage the landscape, which result in a realized mosaic of land use. This mosaic embodies a set of ecosystem service trade-offs between actual and potential patterns of land use. A variety of workers have modeled these trade-offs, which frequently take the form of economically productive provisioning services traded off against ecologically critical supporting or regulating services (Montgomery et al. 1994, Haight 1995, Montgomery et al. 1999, Carlson et al. 2011, Lester et al. 2013). Put bluntly, it is impossible to have everything, and maximizing a provisioning service such as agricultural output results in reductions of supporting, regulating, or cultural services as well as other provisioning services (Naidoo and Ricketts 2006, Ditt et al. 2010, Moilanen et al. 2011, Sandker et al. 2012, van Berkel and Verburg 2014). However, inefficient allocation of land to various forms of land use leads to landscape-service provision below the biophysical optimum. When land use is not efficient, the question of interest changes from "Is it possible to increase provisioning service supply?" to "How can land use support long-term, sustainable supply of multiple services within existing limits?"

Models of ecosystem-service provision in real landscapes have begun to address this question. Such models predict provision of services of interest across both actual and potential mosaics of land use. In spatially explicit models (Lichtenstein and Montgomery 2003, Polasky et al. 2005, Nelson et al. 2009, Ditt et al. 2010, van Berkel and Verburg 2014), management choices are constrained by biophysical suitability for various forms of land use. Models that elucidate efficiency frontiers-curves representing potential land-use arrangements that would optimize provision of ecosystem services of interest - for given landscapes, go a step further, suggesting optimal patterns of land use for production of services (Polasky et al. 2008, Lester et al. 2013). These models suggest that win-win situations may be biophysically possible (Naidoo and Ricketts 2006, Polasky et al. 2012). Given current inefficient management of the landscape, consideration of more efficient potential land-use arrangements may improve regional provision of a variety of economic, environmental, and cultural ecosystem services (Lichtenstein and Montgomery 2003, Polasky et al. 2005, 2008, Nelson et al. 2009), despite trade-offs at smaller spatial and temporal scales.

Here, I present empirically derived models that explore the dynamics of trade-offs between the supply of provisioning and supporting ecosystem services generated on smallholder family farms in eastern Paraguay. To model ecosystem-service provision, I analyze data from this system as well as parameters drawn from the grey and published literature. Following Cavender-Bares and colleagues' (2015) simple analytic framework for sustainability, I characterize the underlying biophysical constraints on this system and efficient trade-offs in provisioning and supporting ecosystems. Given these constraints and trade-offs, I then describe factors that impede sustainable management and potential pathways for more sustainable outcomes. I apply this framework to a system described in earlier work (Grossman 2012), generating a spatially implicit model that, through various instantiations, reflects realized and potential ecosystem-service provision from smallholder farms in eastern Paraguay. This model treats individual smallholders as landscape managers who assign various segments of their holdings to assorted land uses. Such an approach allows for characterization of the trade-offs between supporting and provisioning services that these smallholders negotiate as they contribute to regional patterns of landscape management in the threatened Atlantic Forest ecoregion. 


\section{METHODS}

\section{Study system}

In a mixed-methods case study approach involving interviews with heads of farming families who had invested in eucalyptus plantation forestry, I assessed silvicultural management (Grossman 2012) and land-use practices and attitudes (Grossman, personal data) among smallholders in four Paraguayan departments located in the Paraguayan Atlantic Forest ecoregion. This investigation took the form of a holistic, multiple-case study (sensu Yin 2003) in which households were treated as distinct cases.

Grossman (2012) provides a complete discussion of the study population, case-study methodology, and quantitative and qualitative data analysis. In brief, the foregoing case study is drawn from interviews with one or two heads of households of 38 rural smallholder families in eight communities distributed across four Paraguayan departments (Fig. 1) conducted from April-October 2011. I conducted all interviews in Guaranì, the participants' language of choice.

Fig. 1. Study system, as described in Grossman (2012).

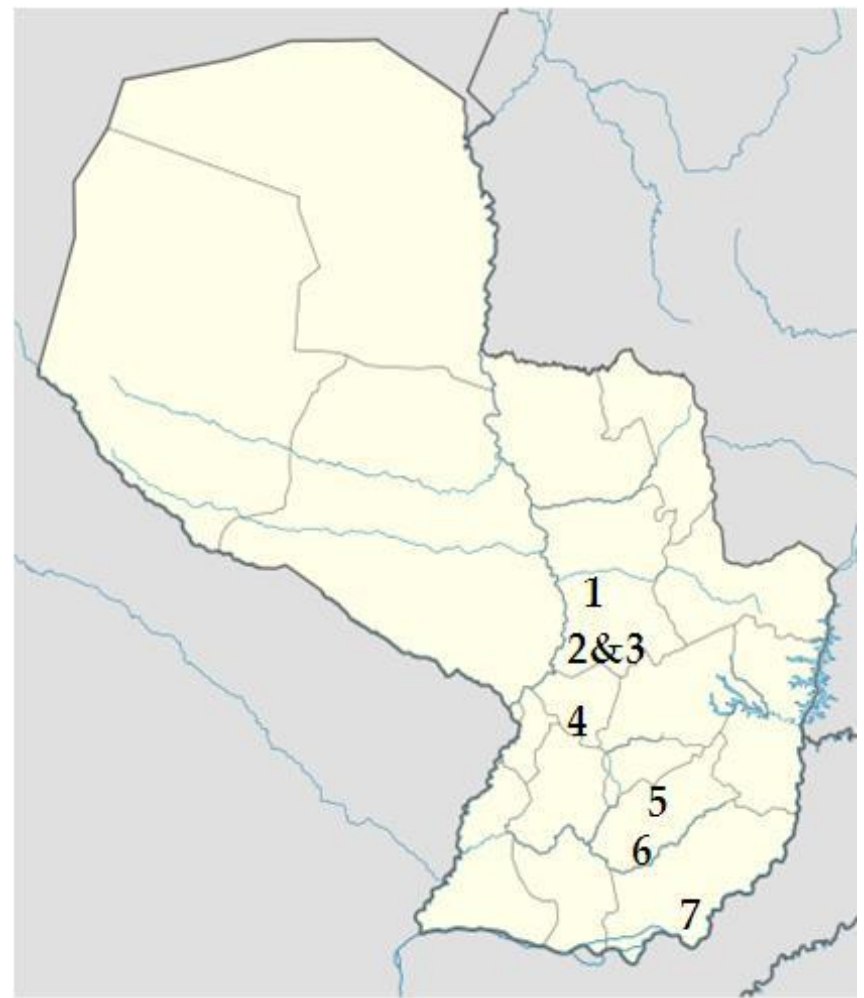

Notes: Study communities were located in seven municipalities in these four departments of Paraguay:

San Pedro: (1) San Pedro de Ycuamandiyú; (2) Guayaibí; (3) San Estanislao de Kostka

Cordillera: (4) Tobatí

Caazapá: (5) General Higinio Morínigo; (6) San Juan Nepomuceno

Itapúa: (7) Alto Verá
All villages were located in rural communities in eastern Paraguay (Paraguay Oriental). Paraguay is one of just two landlocked South American countries and is located between latitudes $19^{\circ}-28^{\circ} \mathrm{S}$ and longitudes $54^{\circ}-63^{\circ} \mathrm{W}$. Its climate is subtropical to tropical, and the major broad-scale environmental pattern is the split between the Chaco Desert in the northwest, and eastern Paraguay. Over $95 \%$ of the population is located in eastern Paraguay, a subtropical region with summer from October-March and winter from May-August. The region's topography is generally flat, with occasional rolling hills providing the most dramatic changes in relief. Paraguay's population of 6.69 million is growing rapidly, at $1.7 \% / \mathrm{yr}$, with roughly one-third of the population in the vicinity of Asunción and two-thirds living in urban areas (United Nations Statistics Division 2013, World Bank 2014). Although urban Paraguayans increasingly find employment in the service sector, the main economic activities of study participants consisted of farming and ranching. Participants cultivated the following crops and animals to meet subsistence needs: cassava, corn, peanuts, beans, various produce, chickens, ducks, guinea fowl, pigs, sheep, goats, and cattle. They also grew a variety of cash crops, including corn, sesame, cotton, soy, wheat, watermelon, pineapple, banana, citrus, yerba mate, and tung. Many engaged in production forestry of exotic timber species. Village sizes ranged from a few dozen households to 200-300. On average, participants were from households of 5.4 individuals and owned 17.7 ha of land, with 4.6 ha devoted to row crops, 5.7 ha devoted to cattle ranching, and 4.4 ha consisting of forest cover (Grossman 2012).

\section{General ecosystem-services model}

Parcels and land uses

The general model presented here quantifies the predicted value of indices of provisioning and supporting ecosystem-service supplies given various realized and potential patterns of smallholder land use in the study system. The model assumes that landscapes managed by smallholder farmers are comprised of mutually exclusive properties, or "parcels," each owned and managed independently by one family.

Each parcel, in turn, is exhaustively assigned to mutually exclusive management systems, or "land uses." Four land uses are permitted in the model (Table 1). These idealized land uses represent common agroecological and natural systems in rural farming communities in the Atlantic Forest ecoregion (Ministry of Agriculture and Livestock 2008, 2009, 2011): (1) annual subsistence row cropping, (2) cattle pasture, (3) eucalyptus plantation forestry, and (4) natural ecosystem coverage. Homes, outbuildings, gardens, small animal pens for domestic meat production, and other forms of land use occupy relatively small portions of parcels and contribute very little to the ecosystem services of interest in this study. Therefore, they are excluded from the model. In reality, land use varies both regionally and idiosyncratically across the study system. The four idealized land uses I used to construct the presented model are merely representative of forms of agricultural production, forestry, and natural ecosystem fragments in the region. For instance, "subsistence" land use represents subsistence production of cassava, corn, beans, peanuts, and sugar cane. In the study system, subsistence versus commercial production of these important crops varies largely only in terms of scale. As such, it is appropriate 
to generalize findings related to this land-use type to situations in which smallholders engage in low-input, small-scale commodity farming.

Table 1. Land uses in the general ecosystem-service model.

\begin{tabular}{ll}
\hline \hline Land use & Description \\
\hline Subsistence & $\begin{array}{l}35 \% \text { cassava, 35\% corn, } 10 \% \text { beans, } 10 \% \text { peanuts, } 10 \% \\
\text { sugar cane }\end{array}$ \\
Pasture & $\begin{array}{l}\text { Cattle pasture assuming } 35 \mathrm{~kg} / \mathrm{ha} / \mathrm{yr} \text { beef production } \\
\text { (Paraguay Rural Association 2010) }\end{array}$ \\
Fatural forest & $\begin{array}{l}\text { Following the suboptimal case of wood from a poorly } \\
\text { managed natural forest (Ministry of Agriculture and }\end{array}$ \\
Eucalyptus & $\begin{array}{l}\text { Livestock 2011) } \\
\text { Based on a firewood and log/lumber plantation with } \\
\text { plantation }\end{array}$ \\
& Agriculture and Livestock 2011)
\end{tabular}

\section{Ecosystem services}

The provisioning ecosystem service modeled in this study is a productivity index representing the annual, per ha proportion of a smallholder family's subsistence needs met by agriculture and forestry on the family's parcel. Rural smallholders like those considered in this study rely both on subsistence and commercial production to meet basic needs (Red Rural 2012). As such, a meaningful metric of provisioning services should account both for productivity of subsistence agriculture and silviculture as well as commercially productive activities (Carlson et al. 2011). The index draws on publications of the Paraguayan Ministry of Agriculture and Livestock (MAG), which provide reasonable estimates of expected agricultural and silvicultural productivity and commodity prices. This allowed me to estimate gross annual income per parcel ha for each land-use type (Table 2). Because agricultural inputs vary widely over the study system and are heavily affected by private and public assistance, informal labor and markets, access to local farmers' cooperatives, and relative access to externalized natural capital, I used gross rather than net income in developing this provisioning-service metric and discuss the outcomes of this choice further below. For each study participant, gross productivity and income is weighted against parcel size, family size, and predicted subsistence needs to produce a measure of annual, per ha proportion of needs met on each smallholder's parcel. A value of 0.50 , for instance, would indicate that productivity from one ha of a given participant's parcel meets $50 \%$ of her family's subsistence needs.

The supporting ecosystem service modeled in this study is a composite index measuring the supply of three supporting ecosystem services - forest bird biodiversity, soil organic carbon content, and aboveground annual net primary productivity (NPP) -relative to what would be expected in a stand of high-quality Atlantic Forest (Table 3).

I define forest bird biodiversity as the species richness of forestadapted birds expected in a given land use type divided by the forest-adapted bird species richness expected in a stand of Atlantic Forest. Biodiversity is a prima facie ecosystem service (Mace et al. 2012) and a well-established driver of ecological function (Hooper et al. 2005, Balvanera et al. 2006, Rey Benayas et al. 2009, Hussain and Tschirhart 2013). It is also widely measured and reported on relative to other more diffuse and less charismatic supporting services. To calculate estimates of this service for the study system, I consulted studies of avian species richness in natural forests, agroforests, tree plantations, pastures, and row crop fields in the Paraguayan, Brazilian, and Argentine Atlantic Forest (Table 4). The Atlantic Forest is a global biodiversity hotspot distinguished by its high population of endemic bird species and the corresponding high level of scholarly and popular interest in the ecoregion's bird diversity (Myers et al. 2000).

Table 2. Estimates of gross income (\$U.S./ha/yr) for individual crops and land-use classes.

\begin{tabular}{|c|c|c|}
\hline Parameter & Valuet & Source \\
\hline \multicolumn{3}{|l|}{ Crops } \\
\hline corn & $\$ 450.00$ & $\begin{array}{l}\text { Ministry of Agriculture and Livestock } \\
2008,2010\end{array}$ \\
\hline cassava & $\$ 201.00$ & $\begin{array}{l}\text { Ministry of Agriculture and Livestock } \\
2010\end{array}$ \\
\hline beans & $\$ 240.00$ & $\begin{array}{l}\text { Ministry of Agriculture and Livestock } \\
2010\end{array}$ \\
\hline peanuts & $\$ 833.50$ & $\begin{array}{l}\text { Ministry of Agriculture and Livestock } \\
2010\end{array}$ \\
\hline sugar cane & $\$ 980.00$ & $\begin{array}{l}\text { Ministry of Agriculture and Livestock } \\
2010\end{array}$ \\
\hline yerba mate & $\$ 524.92$ & $\begin{array}{l}\text { Ministry of Agriculture and Livestock } \\
2011\end{array}$ \\
\hline grafted orange & $\$ 1,200.00$ & $\begin{array}{l}\text { Ministry of Agriculture and Livestock } \\
2008\end{array}$ \\
\hline \multicolumn{3}{|l|}{ Land uses } \\
\hline pasture & $\$ 40.94$ & $\begin{array}{l}\text { Paraguay Rural Association 2010, } \\
\text { Ministry of Agriculture and Livestock } \\
2010\end{array}$ \\
\hline natural forest & $\$ 44.00$ & $\begin{array}{l}\text { Ministry of Agriculture and Livestock } \\
2011\end{array}$ \\
\hline $\begin{array}{l}\text { eucalyptus } \\
\text { plantation }\end{array}$ & $\$ 727.04$ & $\begin{array}{l}\text { Ministry of Agriculture and Livestock } \\
2011\end{array}$ \\
\hline
\end{tabular}

$\uparrow$ Assumes an exchange rate of 5,000 Guaraníes $=\$$ USD 1.00

$\$$ Cassava values represent a quarter of the market price for the amount of cassava grown on 1 ha. This reflects the poor market for cassava in the interior and the common use of cassava for animal fodder.

It is appropriate, then, to treat avian diversity as a surrogate (sensu Plaza Pinto et al. 2008) for the retention of high-quality native land cover (Harvey et al. 2006), if not for the retention of diversity in other taxa (Wolters et al. 2006). Furthermore, different bird species have different habitat requirements, such that conversion of preserved stands of the Atlantic Forest to other land uses, e.g., pasture, alters both aggregate species richness and composition of bird communities, e.g., forest-adapted species are replaced by openadapted ones (Cockle et al. 2005, Uezu et al. 2008). To capture the degree to which preconversion species distributions are retained, I represent bird diversity in this model as the proportion, relative to those that would be encountered in preserved Atlantic Forest fragments, of forest-adapted bird species expected in each land-use type (Table 4). Because local biodiversity levels are expected to saturate - or increase more slowly - with increasing spatial extent (MacArthur 1965, Terborgh and Faaborg 1980), I modify predictions of bird diversity in a way that simulates saturation at high diversity levels. 
Table 3. Components of a composite index of supporting ecosystem services.

\begin{tabular}{lccc}
\hline \hline & $\%$ Forest birds & $\%$ Soil & $\%$ Aboveground net \\
\hline Land use & species richness & carbon & primary productivity \\
Subsistence & $7 \%$ & $56 \%$ & $55 \% \dagger$ \\
Pasture & $7 \%$ & $82 \%$ & $170 \%$ \\
Natural forest & $100 \%$ & $100 \%$ & $100 \%$ \\
Eucalyptus plantation & $14 \%$ & $92 \%$ & $34 \%$ \\
Citrus/yerba mate plantation & $16 \%$ & $96 \%$ & $34 \%$ \\
\hline
\end{tabular}

$\dagger$ Based on productivity estimates (as in Table 2).

Notes:

All services are given as percentages of the value that would be expected from natural Atlantic Forest cover.

The composite index is an average of all three individual services.

Sources: Raich et al. 1991, Fearnside and Barbosa 1998, Marsden et al. 2001, Freixo et al. 2002, Guo and Gifford 2004, Cockle et al. 2005, Laclau et al. 2008, Uezu et al. 2008, Pereira et al. 2009, Fialho and Zinn 2012, J. J. Grossman, unpublished data.

Table 4. Species richness of forest-adapted birds as a proportion of that expected in a stand of high-quality Atlantic Forest.

\begin{tabular}{|c|c|c|}
\hline Land use & Value & Source \\
\hline tence & & \\
\hline & & \\
\hline$t$ & & \\
\hline$n$ & & $001 \mid$ \\
\hline \multicolumn{3}{|c|}{$\begin{array}{l}\text { †Obtained by dividing the number of forest species observed in the } \\
\text { "L1" matrix by the } 43 \text { species observed in control plots and large } \\
\text { patches } \\
\$ \text { Obtained by dividing the number of forest species observed in the } \\
\text { agroforest patches by the number of species observed in control plots } \\
\text { and large patches } \\
\$ 2.9 \text { species/ha } \\
\text { |Obtained by dividing the number of forest species in eucalyptus } \\
\text { plantations by the number of species in Atlantic Forest fragments }\end{array}$} \\
\hline
\end{tabular}

As an ecosystem service, soil carbon retention supports the provision of numerous benefits to smallholders, including fertility for agricultural production on the local scale and sequestration of greenhouse gases on the global scale (Moreira and Fageria 2011, Fialho and Zinn 2012). Carbon soil changes rapidly with conversion of subtropical forest to alternative land uses (Guo and Gifford 2002). Retention of both above and belowground carbon in forested and reforested lands is not only critical as a supporting service that provides direct benefits to smallholders, it is also a potential source of revenue via institutionally mediated payments for carbon sequestration (Naidoo and Ricketts 2006). I represent relative soil carbon retention of various land uses in the study system as the quantity of soil carbon documented for comparable land uses reported in the grey literature divided by soil carbon expected for natural Atlantic Forest stands (Table 3).

Finally, aboveground NPP also provides benefits to smallholders by supporting provisioning services, e.g., generating woody and consumable biomass, soil fertility, and water and nutrient cycling (Haberl et al. 2007). As for soil carbon, I estimate the proportion of marginal NPP represented by various modeled land uses by dividing values taken from the literature for each land-use type by the expected annual marginal NPP documented for natural Atlantic Forest (Table 3). By combining measures of NPP, soil carbon, and bird biodiversity to form a composite index, I intend to represent, in simple terms, the breadth of supporting services provided by smallholder parcels in the study system.

Ecosystems provide diverse services, and the ecological patterns and processes that provide these services can interact in complicated ways (Bennett et al. 2009). Additionally, humans value a wide variety of ecosystem services (Millennium Ecosystem Assessment 2005) and do not rely on or manage landscapes to produce only one provisioning or supporting service at a time. I model composites of relative service provision in the present study to elaborate a simple, interpretable model. The provisioning service index is reasonable as a metric that quantifies both subsistence and commercial agricultural, and silvicultural production-benefits that dominate much of smallholder concern with ecosystem services (Carlson et al. 2011). In contrast, smallholders rely on a variety of critical supporting services. Incorporating measures of supply of three critical supporting services relative to their production in natural Atlantic Forest provides for a nuanced but simple metric of supporting services.

The two ecosystem-service indices modeled are reasonable given my objective of assessing the consequences of land-use dynamics in the study system for sustainable management of the Atlantic Forest ecoregion. Crop and forestry production are major drivers of deforestation and ecological degradation, both generally (Geist and Lambin 2002, Green et al. 2005, Phalan et al. 2011) and in the study system (Goerck 1997, Chiarello 1999, Rômulo et al. 2003, Naidoo and Adamowicz 2006, Zurita et al. 2006, Uezu et al. 2008). The documentation of this relationship provides evidence of the mechanism linking agricultural/silvicultural income and supporting service decline.

The general ecosystem-service model, then, provides estimates of the per-ha productivity index relative to household subsistence requirements $(P)$ and the composite supporting services index relative to natural forest $(S)$ for each of four land uses typical of smallholder parcels in eastern Paraguay (Table 5). Aggregate $P$ and $S$ values are calculated as:

$$
P=\sum_{i=1}^{4} k_{i} \times c_{i} \times p_{i}
$$




$$
S=\sum_{i=1}^{4}\left(b_{i}+\left(b_{i} \times\left(1-b_{i}\right)\right)\right) \times p_{i}
$$

where $k_{i}=$ commodity productivity for a land-use class $i, c_{i}=$ commodity price for a land-use class $i, p_{i}=$ the proportion of a parcel devoted to a land-use class $i$, and $f=$ family size for a given participant. Additionally, $b_{i}=$ proportion of forest bird species richness for land use $i$ relative to the maximum, and $K_{i}$ and $N_{i}$ represent the same proportions for soil carbon and net primary productivity, respectively. The term $b_{i} \times\left(1-\mathrm{b}_{i}\right)$ modifies $b_{i}$ to account for saturation in the species richness-area relationship while retaining the $[0,1]$ scale of $b_{i}$. The annual per capita subsistence requirements for rural smallholders in eastern Paraguay is estimated as U.S. \$203.19 (Red Rural 2012).

Table 5. Expected annual per ha proportion of all household subsistence needs met $(P)$, and supporting service composite index relative to natural forest $(S)$, for each of four land uses.

\begin{tabular}{lll}
\hline \hline Land-use code and name & $P_{\dagger}^{\dagger}$ & $S$ \\
\hline Subsistence & 0.41 & 0.39 \\
Pasture & 0.04 & 0.86 \\
Natural forest & 0.04 & 1 \\
Eucalyptus plantation & 0.70 & 0.47 \\
\hline
\end{tabular}

$\uparrow$ Calculated for a family of 5.15 , the average size in the study system (Red Rural 2012)

A typical smallholder parcel in the study system was divided into several different land uses (Grossman 2012). The model instantiations described below allow for the quantification of expected output of provisioning and supporting service form heterogeneously managed parcels given both observed and potential patterns of land use.

\section{Model instantiations}

Realized trade-offs

In the first instantiation of the general ecosystem-services model, I calculated $P$ and $S$ for all 38 study participants' parcels and plotted $P$ and $S$ for the population against one another (Fig. 2). This model instantiation illustrates realized trade-offs of $P$ versus $S$ in the study system, assuming the general model parameterizations described above.

\section{Efficiency frontier}

To develop an efficiency frontier representing optimum land uses for the production of both $P$ and $S$, I simulated all potential allocations of parcels to the four modeled land uses in increments of 0.1 . In calculating $P$ for this instantiation, I set the variable $f$ equal to 5.15 , the mean family size per Red Rural (2012) in the study system. This simulation yielded 106 unique potential assignments of fractions of parcels to different land uses. An efficiency frontier is derived from this model through the selection of the 11 points that define a curve for which, at a given value of $P$, no higher value of $S$ is possible (Fig. 3). This curve represents the efficiency frontier for the general ecosystem-services model.
Fig. 2. Ecosystem service trade-offs as predicted by realized smallholder land-use patterns.

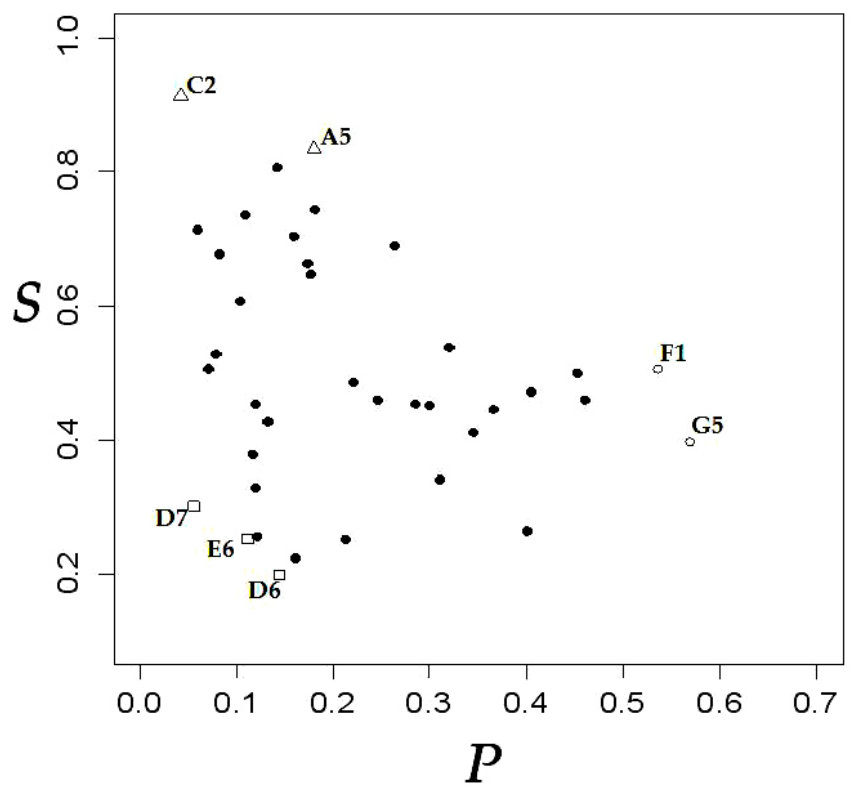

Notes:

$S=$ supporting service, $P=$ provisioning service

The figure reflects estimates of the supporting service index relative to Atlantic Forest cover and annual per ha proportional provisioning of household subsistence needs on 38 smallholder farms in the Paraguayan Interior Atlantic Forest.

Participants C2 and A5 (represented by triangles) and F1 and G5 (represented by open circles) have achieved relatively efficient land use, whereas participants D6, D7, and E6 (represented by squares) produce low levels of both $P$ and $S$.

\section{RESULTS}

\section{Realized trade-offs}

Modeled ecosystem-service provision from realized smallholder land-use patterns in the study system (Fig. 2) illustrates the tradeoff between the provisioning service of productivity as a proportion of annual household subsistence needs per ha and a composite of supporting services relative to those provided by high-quality Atlantic Forest.

One household, C2, demonstrated a very high predicted supply of supporting ecosystem services, accompanied by low levels of provisioning services (Fig. 2). This household was associated with the highest rate of supporting service provision-91.4\% of services expected from stands of Atlantic Forest - coupled with the lowest average annual per ha productivity in the study population $-4.2 \%$ of subsistence needs met (Table 6). These extreme levels of provision of one service associated with participant C2 are interpretable in light of the heterogeneous land-use patterns characterizing the study region.

Household C2 is located in a community at the remote interior of the department of Caazapà, south of the municipal seat of 
San Juan Nepomuceno (Fig. 1). This community lies just inside the eastern Paraguayan agricultural and colonization frontier. Most participants living there are only first- or second-generation inhabitants of the community. Although most reported holding legal title to some of their lands, the parcels managed by some participants were quite large and often included untitled lands that were appropriated by participants through de facto use for cattle ranching and, occasionally, row cropping. Participant C2 reported that his parcel covered 110 ha of land, three-quarters of which was still forest. His family practiced small-scale ranching, some row cropping, and plantation forestry. This extensive, lowintensity pattern of land use generated low per ha annual income and a high predicted retention of forest bird biodiversity, soil carbon, and NPP.

The reverse case held for two households, F1 and G5, which were associated with high predicted provisioning service values and low supporting service values (Fig. 2). For these participants, the ecosystem-services model generated $P$ values upwards of $50 \%$, indicating that, on average, agricultural and silvicultural production on each ha of their parcels met over half of household subsistence needs. Values of the $S$ index for these participants were intermediate relative to other households (Fig. 2). Comparison of the two participants is instructive: the $\sim 3 \%$ higher provisioning index in G5 is associated with a $\sim 11 \%$ drop in supporting service provision compared to F1 (Table 6).

Table 6. Realized and potential production of supporting $(S)$ and provisioning $(P)$ ecosystem services for selected households.

\begin{tabular}{llllll}
\hline \hline $\begin{array}{l}\text { House- } \\
\text { hold }\end{array}$ & $\begin{array}{l}\text { Depart- } \\
\text { ment }\end{array}$ & $\begin{array}{l}\text { Realized } \\
S\end{array}$ & $\begin{array}{l}\text { Realized } \\
P\end{array}$ & $\begin{array}{l}\text { Optimal } P, \\
\text { given } S\end{array}$ & $\begin{array}{l}\text { Optimal } S, \\
\text { given } P\end{array}$ \\
\hline A5 & Caazapá & $83.5 \%$ & $18.0 \%$ & $70.0 \%$ & $99.3 \%$ \\
C2 & Caazapá & $91.4 \%$ & $4.2 \%$ & $54.7 \%$ & $99.9 \%$ \\
D6 & Caazapá & $19.9 \%$ & $14.4 \%$ & $70.0 \%$ & $99.6 \%$ \\
D7 & Caazapá & $30.2 \%$ & $5.6 \%$ & $70.0 \%$ & $99.9 \%$ \\
E6 & San & $25.3 \%$ & $11.2 \%$ & $70.0 \%$ & $99.8 \%$ \\
& Pedro & & & & \\
F1 & San & $50.6 \%$ & $53.6 \%$ & $70.0 \%$ & $91.0 \%$ \\
& Pedro & & & & \\
G5 & Itapúa & $39.8 \%$ & $56.9 \%$ & $70.0 \%$ & $89.8 \%$ \\
\hline
\end{tabular}

Households F1 and G5 are located in the departments of San Pedro and Itapúa (Fig. 1), both departments in which agricultural productivity is more lucrative than is the case in Caazapá. The Itapúa households surveyed, all located in the municipality of Alto Verá, were generally engaged in high levels of commercialized agriculture and forestry, with relatively little land devoted to subsistence farming or retention of native forest. Large-scale agriculture is more prevalent in Itapúa than in Caazapá or Cordillera and smallholders are generally better capitalized. As a result, the regional landscape is much more heavily dominated by soy and wheat row cropping and, to a lesser extent, cultivation of tree crops such as yerba mate and grafted citrus. Smallholders in San Pedro similarly benefit from high levels of capitalization and technical assistance. As a result, commercial cultivation of tobacco, pineapple, banana, and other input- and labor-intensive crops is very profitable in San Pedro. These economic qualities of Itapúa and San Pedro are reflected in the predicted ecosystem-service provision for parcels located in the two departments.
Inspection of the $P$ - and $S$-provision values corresponding to the parcels of participants F1, G5, C2, and A5-which, like C2, are located in Caazapà and had relatively high retention of supporting services-provides a rough approximation of the current nonbiophysical constraints on optimal ecosystem-service provision (Fig. 2). Three households-D6, D7, and E6 - are highlighted as examples of parcels with the lowest predicted supply of both provisioning and supporting services (Fig. 2). These large households owned parcels with little land retained in natural forest cover, constraining supply of both classes of ecosystem services (Table 6).

Comparison of these realized trade-offs in service provision with the efficiency frontier-simulated given the parameterized general ecosystem-services model - can suggest ways in which current land-use practices fall short of optimal management of the modeled ecosystem service trade-off.

\section{Efficiency frontier}

Within the general ecosystem-services model, the efficiency frontier (Fig. 3) illustrates the optimal series of trade-offs among provisioning and supporting services that smallholders can pursue. Because the general model only predicts trade-offs between two services and does not incorporate the spatial heterogeneity of the study system, the frontier merely represents a biophysical trade-off between eucalyptus forestry-the most productive, that is, $P$-maximizing, land use - and forest coverthe most conservative of supporting services, that is, $S$ maximizing, land use. The position of the frontier suggests that smallholders can produce optimal levels of both ecosystem services when they divide their land up into eucalyptus plantations and forest. Given the saturating nature of the $S$ metric, increasing dedication of land to forest retention has less of an effect when $S$ is already high.

Superimposition of the empirically derived model instantiation over the ideal efficiency frontier (Fig. 4) demonstrates that, with the exception of participant $\mathrm{C} 2$, smallholders appear to be operating far below the maximally biophysically efficient tradeoff between provisioning and supporting ecosystem services. Comparison of the curve representing the most efficient realized land uses and the efficiency frontier illustrates the degree to which more efficient land use is biophysically possible. Households A5, $\mathrm{C} 2, \mathrm{~F} 1$, and G5, which already realize fairly high values for at least one index of service supply, could, if production devoted to row crops and pasture were switched to other land uses, realize increases in both $P$ and $S$ (Table 6). Gains in provision of both services would be even more extreme for households further from the efficiency frontier. Comparison of households C2 and E6 illustrates this potential (Fig. 2). There is only a 7\% difference between the values of provisioning services associated with these participants, but the $\mathrm{C} 2$ parcel, which lies very close to the efficiency frontier, generated a supporting service index over three and a half times larger than that of E6. However, the trade-off discussed here represents only what is possible for these households given the production systems that are presently and potentially available to smallholders. A variety of economic, political, and cultural factors restrain households such as E6 from achieving more efficient trade-offs between provisioning and supporting services. 
Fig. 3. Trade-offs between the supporting service index relative to Atlantic Forest cover and annual per ha proportional provisioning of household subsistence needs in the general ecosystem service model.

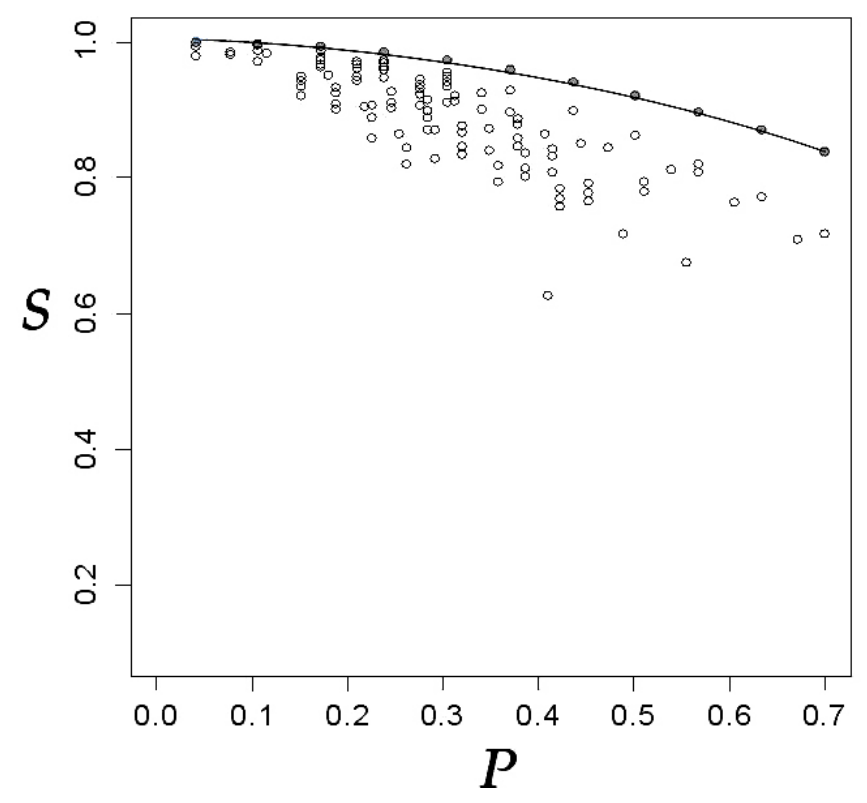

Notes:

$S=$ supporting service, $P=$ provisioning service

Grey circles $=$ simulated efficiency frontier, Open circles $=$ simulated, suboptimal land-use arrangements

\section{DISCUSSION}

The empirical (Fig. 2) and simulated (Fig. 3) instantiations of the general ecosystem service model presented demonstrate a tradeoff between predicted levels of provisioning and supporting ecosystem services among smallholders' parcels in the Paraguayan Atlantic Forest. Under maximally efficient land-use scenarios (Fig. 3), investment in ecologically protective land uses, such as conservation of Atlantic Forest cover, increases retention of forest-associated supporting services, specifically bird biodiversity, soil carbon, and NPP, at the cost of a provisioning service, that is, subsistence and commercial productivity. The reverse is true when a more profitable but ecologically disruptive land use, such as eucalyptus cultivation, is prioritized. Yet this trade-off is only relevant when smallholders make maximally biophysically efficient land-use decisions. When realized land-use patterns fall below an efficiency frontier (Fig. 4), it is not necessary to sacrifice productivity for sustainability (Polasky et al. 2012). Policies and land-use practices that enable smallholders to overcome constraints to optimal land use can thus allow for greater landscape-level output of provisioning and supporting services without requiring trade-offs.

\section{Constraints to sustainability}

Cavender-Bares et al. (2015) suggest that, following the characterization of the biophysical mechanisms underlying ecosystem-service provision, and the trade-offs between provisioning and supporting services (Fig. 3), it is necessary to explore the stakeholder preferences and the systemic barriers that constrain sustainable resource use. In this case, comparison of the empirical and simulated instantiations of the general ecosystem service model (Fig. 4) speaks to stakeholder preferences and constraints to sustainability.

Fig. 4. Estimates of the supporting service index relative to Atlantic Forest cover and annual per ha proportional provisioning of household subsistence needs on 38 smallholder farms in the Paraguayan Interior Atlantic Forest.

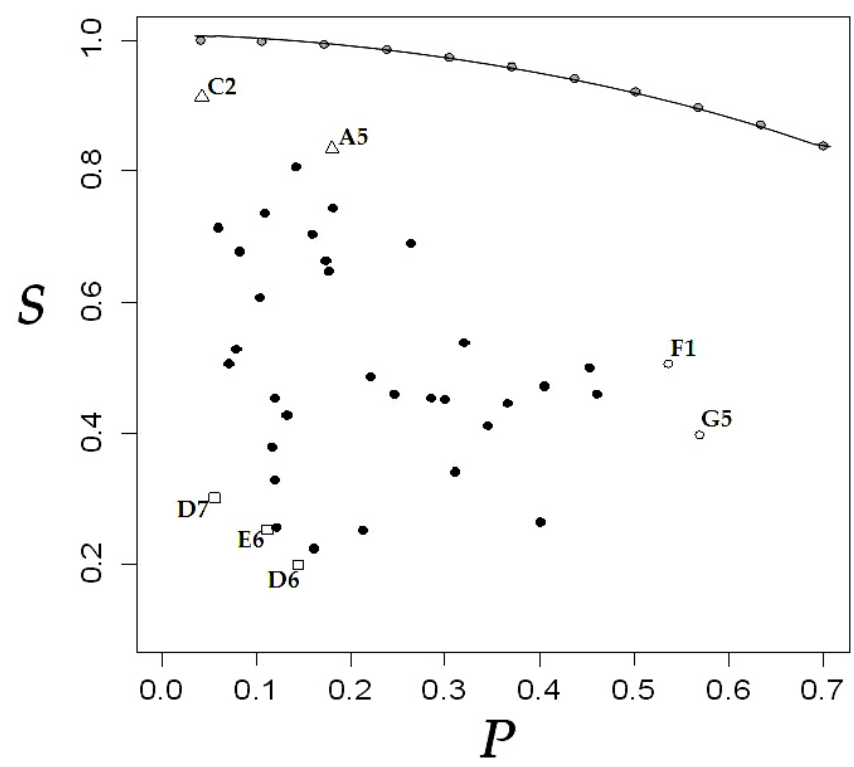

Notes:

$S$ =supporting service, $P=$ provisioning service

Grey circles=simulated efficiency frontier, All other points= realized smallholder ecosystem service trade-offs

Participants C2 and A5 (represented by triangles) and F1 and G5 (represented by open circles) have achieved relatively efficient land use, whereas participants D6, D7, and E6 (represented by squares) produce low levels of both $P$ and $S$

Smallholders may not assign their parcels to various land uses in the most efficient way out of a preference for diversity in livelihood management (Ellis 1998). The efficiency frontier shown in Fig. 3 indicates that splitting land use between eucalyptus plantation forestry and conservation of natural forest provides the biophysically most efficient provision of ecosystem services. Yet few, if any, smallholders in the study system would choose to devote their land to only these two - or, for that matter, any two -land uses. Rather, even for well-off smallholders who can purchase food from neighbors or markets, it is important to engage in some subsistence row cropping and cattle ranching. It is culturally important to have homegrown cassava for consumption with meals (Finnis et al. 2012) and fresh corn to make "chipa guasu," a traditional corn bread. Furthermore, since many provisioning services are not valued economically (Costanza et al. 1999, Naidoo and Ricketts 2006), a primary focus on economic value may lead smallholders to prefer provisioning 
over supporting services. As such, participants who value their identities as farmers and/or ranchers and who face economic constraints will find it difficult to convert all managed lands to eucalyptus plantations or other high-yielding tree crops. These heads of household do not manage for efficient provision of ecosystem services but, rather, for secure provision of a satisfying, quality livelihood.

Historical contingency also constrains efficient land use among smallholders in the study system. Eastern Paraguay has undergone severe deforestation over the lifetime of most study participants. Between 1989 and 2000 alone, $50 \%$ of the forest cover of the Paraguayan Atlantic Forest was lost (Huang et al. 2007) with deforestation continuing through the 2000-2010 period (Aide et al. 2012). As a result, most study participants have inherited deforested landscapes and have not had the time, resources, or knowledge necessary for reforestation. This pattern is manifest in present land-use patterns. On average, smallholders in the study population owned a mean of 4.84 ha of forested land, comprising on average only $14.8 \%$ of all holdings (Grossman 2012). Seven participants out of 38 owned no forested lands at all. Given the paucity of remaining forested lands, participants do not have access to the natural ecosystems that provide high levels of supporting services. As a result, they are constrained to low levels of $S$ in the trade-off space structured by the ecosystemservices model. Smallholders, such as C2, who have large, forested holdings or live at the wave front of agricultural colonization are at least partially released from such historical constraints (Carter et al. 1996) and have not occupied their parcels for long enough to convert their forested land to other land uses.

Restricted access to technical knowledge about new techniques and preferences in favor of historically popular land uses may also constrain more efficient land use (Bravo-Ureta and Evenson 1994). Smallholder investment in eucalyptus plantation forestry, native agroforestry, and cultivation of yerba mate and grafted citrus provides higher levels of many supporting and provisioning services than does row cropping and cattle ranching (Tables 2,4). The same win-win scenario holds when farmers adopt techniques of sustainable production systems such as no-till and wildlifefriendly farming (Ministry of Agriculture and Livestock 2011, Tscharntke et al. 2012). Yet these systems, which would enable smallholders to move further toward the upper right quadrant of the trade-off space shown in Figs. 2-4, often require extensive training, technical knowledge, and new equipment (Evans 1988). The families described in the present study had all adopted eucalyptus plantation forestry, but were often uncertain about the best silvicultural practices for the exotic species (Grossman 2012). Their adoption may also entail considerable risk for smallholders (Weisskoff 1992). As unusual and novel practices, they may be less appealing relative to widely practiced and accessible cassava, corn, bean, and peanut cropping or cattle ranching (Hamilton and Bliss 1998, Grossman, unpublished data).

Finally, limited capital resources, positive discount rates, and short time-preference schedules constrain smallholders in the study population from investing in more sustainable land use (Hosier 1989, Shiferaw et al. 2009). The present study addresses economic output in terms of gross agricultural and forestry production. The use of gross measures rather than net measures obscures the reality that many of the optimal land-use arrangements implied by the theoretical efficiency frontier are very expensive to implement and maintain. Most study participants had limited access to capital and were thus constrained to subsistence agriculture and, to a lesser extent, small-scale cattle ranching. These forms of land use are subsidized heavily by (1) natural capital embodied in smallholders' parcels, e.g., soil and trees, and stock, e.g., animals and seed plants, (2) unpaid family labor, and (3) assistance and supplies from the Department of Agricultural Extension. Such subsidies promote land uses such as traditional row cropping and cattle ranching, which produce low levels of both supporting and provisioning services, and thus constrain investment in expensive forms of land use such as plantation forestry (Hamilton and Bliss 1998). Novel and high-input forms of land use such as grafted citrus cultivation were most common in communities where development agencies or the Paraguayan government had provided training and materials to encourage smallholders to innovate.

The realized trade-off envelope (Fig. 2) represented by smallholder parcels A5, C2, F1, and G5 is suggestive of the preferences and systemic barriers discussed above that constrain efficient land use in the study system. Through moderate retention of natural forest, moderate investment in eucalyptus plantations, and cultivation of crops rather than cattle, these smallholders manage their parcels in ways consistent with production of both provisioning and supporting ecosystem services. Generally, these smallholders were eager to invest in new techniques, specifically eucalyptus plantation forestry, and still owned fairly high percentages, $10 \%-50 \%$, of forested land. They live in relatively prosperous communities in which production is better capitalized (Shiferaw et al. 2009) and technical (Bravo-Ureta and Evenson 1994, Evans 1998) and social (Knowler and Bradshaw 2007) support is more common than is the case for other participants. As such, the levels of ecosystem-service provision predicted for these households may be a more realistic goal than those represented by the ideal efficiency frontier (Fig. 4).

\section{Pathways to sustainability}

Smallholder adoption of land uses that provide higher levels of both provisioning and supporting services constitutes an important step towards greater sustainability in the study system. The general ecosystem-services model presented here predicts service provision from only four different land uses that predominate in the study system. In reality, land use is diverse, and each of the four land uses modeled above are representative of many classes of agricultural and forestry output. The eucalyptus land use designation, in particular, stands in for a variety of alternative production systems (Ministry of Agriculture and Livestock 2008, 2011): no-till row crop farming with green manures, sericulture, agroforestry systems (including silvopastoralism), native silviculture, citrus and yerba mate orchards, and cultivation of high-value horticultural crops such as Stevia Cav. cultivars and passion fruit (Passiflora edulis Sims). Like eucalyptus plantations, many of these systems are more profitable and less ecologically disruptive than conventional row cropping and cattle ranching. Yerba mate grown under native trees, for instance, conserves some native Atlantic Forest bird habitat — 66\% in Cockle and colleagues' study (2005) — while also generating considerable commercial income relative to subsistence farming (Table 2). Yet smallholders require external support to move beyond the constraints detailed above and 
successfully adopt and maintain productive, more efficient land use (Shiferaw et al. 2009).

Although modest gains in sustainability are feasible through modification of conventional production systems (Ministry of Agriculture and Livestock 2011), successful adoption of novel, sustainable systems often requires extension and material subsidies (Byron 2001). Extension, whether provided by public agencies, NGOs, or businesses, is a critical first step, raising smallholders' awareness of production systems like eucalyptus silviculture and yerba mate plantations and providing the technological expertise required to establish them (Bravo-Ureta and Evenson 1994). Likewise, material subsidies, whether public or private, are critical to helping smallholders with limited capital invest in input-intensive, sustainable production (Shiferaw et al. 2009). The contrasts in establishment costs between conventional and sustainable systems can be striking. In the study system, eucalyptus and grafted citrus seedlings cost an average of U.S. $\$ 0.14$ and U.S. $\$ 1.80$ respectively (Grossman, unpublished data). As such, the formal establishment cost of a eucalyptus plantation or citrus orchard could reach hundreds or thousands of U.S. dollars, while establishment of row crops with seed or starters from the previous year's harvest entails no formal economic costs. Smallholders are often unable to invest in new production systems under these economic conditions, and are even less likely to do so when they are not confident in their understanding of how to manage them (Hamilton and Bliss 1998). Extension and aid programs that help smallholders to move beyond constraints in both knowledge and materials can facilitate the transition from less sustainable forms of land use, e.g., subsistence row crops, to more sustainable ones, e.g., forestry plantations and orchards.

Farmers' and women's committees ("comités de productores/ mujeres") and community cooperatives ("cooperatives") constitute one main source of the technical and material support that enables smallholders to improve ecosystem service production through more efficient land use (Gattini 2011). Committees, which operate at the community level and generally consist of 12 or more members, act as the central link between national public agencies, e.g., the Ministry of Agriculture and Livestock, or private development and commercial institutions, and Paraguayan families (Molinas 1998). Public and private organizations will often work with committees to organize extension efforts and cash or material subsidies designed to promote investment in new agricultural and forestry systems. Cooperatives, usually located in cities and larger towns, operate both in urban and surrounding rural areas to provide member households with credit, insurance, affordable seeds and tools, and technical assistance (Turner 1998, Vázquez-León 2010). Like committees, cooperatives facilitate the adoption of more efficient land use by helping smallholders to overcome the constraints discussed above and structuring communities of members who share ideas and support one another in adopting new production systems (Evans 1998).

Policy can restrict or facilitate unsustainable land use and thus affect the efficiency of ecosystem-service supply from smallholders' parcels (Sandker et al. 2012, Hirschi et al. 2013). Paraguay's first forestry law, Law 422/73 was passed in 1973, but through the turn of the century, the country lacked a centralized ministry of environmental affairs and a holistic, national environmental policy. To the limited extent that ad hoc environmental policy existed, the Ministry of Agriculture and Livestock was, through 2000, responsible for implementing all environmental law. In 2000, Law 1561/00 created the Secretariat of the Environment (SEAM), which has since shared responsibility with for rule making and enforcement of natural resource policy (Japanese International Cooperation Association 2002, Yanosky and Cabrera 2003). In 2008, Law 3464/08 mandated the creation of the National Forestry Institute (INFONA). Since then, INFONA has served as an increasingly strong, although still significantly underfunded and overextended, forest service charged with monitoring compliance with forestryrelated laws, promoting sustainable use of forest resources, and providing extension services. However, Paraguayan smallholders generally operate independently of forest policy. Although large landowners may be forced to mitigate deforestation or submit to government inspections, enforcement of existing environmental policy is negligible, especially in cases where shortages in available government staff and resources, corruption, or political pressure from e.g., peasants' groups, militate against it (Aguiló-Pastrana 2000, Yanosky and Cabrera 2003). If existing forest policy-such as Law 515/94, prohibiting the export and trafficking of logs, poles, and stakes; Law 536/95, strengthening (re)forestation and plantation establishment; and Law 3663/08, preventing all conversion of forested land to other forms of land use in eastern Paraguay - were enforced more effectively for smallholders and large landowners alike, or new, more restrictive legislation were passed, realized ecosystem-service provision would change, moving upward and to the left along the modeled efficiency frontier (Fig. 4). However, at present, limitations in the enforcement of existing Paraguayan environmental policy work against the role of top-down, national approaches in facilitating more efficient smallholder land management.

Finally, programs and policies that internalize the considerable value of nonprovisioning ecosystem services (Costanza et al. 1997) such as biodiversity and carbon sequestration through payments for ecosystem services (PES; Farley and Costanza 2010) provide another potential pathway to arrangements of efficient land use that are currently economically unviable. Increasingly, PES systems have provided economic incentives for households to adopt land uses that enhance the supply of supporting ecosystem services- yet, absent this support, smallholders like those in the study system often face steep economic pressure to prioritize provisioning service supply (Naidoo and Ricketts 2006).

\section{CONCLUSION}

The general ecosystem service model presented demonstrates the biophysical trade-offs among the quantities of provisioning and supporting ecosystem services produced by smallholder farmers in rural eastern Paraguay. This finding stems from analysis of predicted levels of ecosystem-service provision given realized and simulated patterns of land use. Comparison of realized land use versus a biophysical efficiency frontier for the trade-off between the provisioning service-agricultural and silvicultural output relative to subsistence needs - and the supporting service - a composite of forest bird biodiversity, soil carbon, and net primary productivity - suggests factors that currently constrain study participants from optimally productive land use, and indicate pathways toward more sustainable management of the Paraguayan Atlantic Forest ecoregion. 
Exploration and implementation of practices that will facilitate efficient land use in this and similar systems relies on empirical work that directly assesses changes in ecosystem-service provision across landscapes that are under heterogeneous management. Limited work in eastern Paraguay has assessed some ecosystem structural and functional variables across land-use types (Cockle et al. 2005, Naidoo and Ricketts 2006, Carlson et al. 2011). Yet, critical synthetic comparisons of conventional and sustainable production systems that take into account multiple ecosystem services are still lacking. Furthermore, studies such as my own, which only account for trade-offs between a few, simplified ecosystems services, fail to capture the multidimensionality of ecosystem-service provision. The absence of indifference curves, which represent points of equivalent preference for various combinations of land uses, also limits the model presented here. An empirical study of smallholder preferences for various landuse classes would allow for a model that better predicts actual smallholder behavior. Future work that empirically establishes these curves and the efficiency frontier for trade-offs in multiple ecosystem services provided by the Atlantic Forest ecoregion will advance the development of policy and programs that protect its economic, cultural, and ecological integrity.

\section{Responses to this article can be read online at: http://www.ecologyandsociety.org/issues/responses. $\mathrm{php} / 6953$}

\section{Acknowledgments:}

The author offers his deepest thanks to J. Cavender-Bares for her considerable encouragement in the conceptualization and execution of this paper; her support was invaluable. He also wishes to acknowledge the hospitality, openness, and insight of the Paraguayan study participants and thank $W$. Pearse for programming consultation. Finally, the research described above was carried out with the assistance of colleagues in the U.S. Peace Corps - Paraguay (E. Cabrera, H. Clark, S. Conway, S. EnglandMarkum, L. Gourlie, G. Cooper, M. Nesheim, B. Pattullo, and L. Roberts), the University of Washington School of Environmental and Forest Sciences (I. Eastin), and the University of Minnesota Department of Ecology, Evolution, and Behavior (J. CavenderBares and S. Polasky).

\section{LITERATURE CITED}

Aguiló Pastrana, J. 2000. Proyecto de reforestación en terrenos degradados del Alto Paraná, Paraguay. La problemática social de la tenencia de la tierra. Bois et Forêts des Tropiques 263:53-62.

Aide, T. M., M. L. Clark, H. R. Grau, D. López-Carr, M. A. Levy, D. Redo, M. Bonilla-Moheno, G. Riner, M. J. Andrade-Núñez, and M. Muñiz. 2012. Deforestation and reforestation of Latin America and the Caribbean (2001-2010). Biotropica 45(2):262271. http://dx.doi.org/10.1111/j.1744-7429.2012.00908.x

Balvanera, P., A. B. Pfisterer, N. Buchmann, J. He, T. Nakashizuka, D. Raffaelli, and B. Schmid. 2006. Quantifying the evidence for biodiversity effects on ecosystem functioning and services. Ecology Letters 9(10):1146-1156. http://dx.doi. org/10.1111/j.1461-0248.2006.00963.x

Barona, E., N. Ramankutty, G. Hyman, and O. T. Coomes. 2010. The role of pasture and soybean in deforestation of the Brazilian Amazon. Environmental Research Letters 5(2):1-9. http://dx.doi. org/10.1088/1748-9326/5/2/024002

Bennett, E. M., G. D. Peterson, and L. J. Gordon. 2009. Understanding relationships among multiple ecosystem services. Ecology Letters 12(12):1394-1404. http://dx.doi.org/10.1111/ j.1461-0248.2009.01387.X

Berry, A. 2010. The role of agriculture. Pages 61-84 in A. Berry, editor. Losing ground in the employment challenge: the case of Paraguay. Transaction, New Brunswick, New Jersey, USA.

Bravo-Ureta, B. E., and R. E. Evenson. 1994. Efficiency in agricultural production: the case of peasant farmers in eastern Paraguay. Agricultural Economics 10:27-37.

Brockerhoff, E. G., H. Jactel, J. Carnus, and S. Pawson. 2010. Biodiversity of plantation forests and its relevance for ecosystem functioning. Pages 62-70 in T. Koizumi, K. Okabe, I. Thompson, K. Sugimura, T. Toma, and K. Fumita, editors. The role of forest biodiversity in the sustainable use of ecosystem goods and services in agro-forestry, fisheries, and forestry. Forest and Forestry and Forest Products Research Institute, Ibaraki, Japan.

Brockerhoff, E. G., H. Jactel, J. A. Parrotta, C. P. Quine, and J. Sayer. 2008. Plantation forests and biodiversity: oxymoron or opportunity? Biodiversity and Conservation 17(5):925-951. http:// dx.doi.org/10.1007/s10531-008-9380-X

Byron, N. 2001. Keys to smallholder forestry. Forests, Trees, and Livelihoods 11(4):279-294. http://dx.doi.org/10.1080/14728028.2001.9752396

Cardoso da Silva, J. M., M. Cardoso de Sousa, and C. H. M. Castelletti. 2004. Areas of endemism for passerine birds in the Atlantic Forest, South America. Global Ecology and Biogeography 13(1):85-92. http://dx.doi.org/10.1111/ j.1466-882X.2004.00077.x

Carlson, M. J., R. Mitchell, and L. Rodriguez. 2011. Scenario analysis to identify viable conservation strategies in Paraguay's imperiled Atlantic forest. Ecology and Society 16(3): 8. [online] URL: http://www.ecologyandsociety.org/vol16/iss3/art8/

Carter, M. R., B. L. Barham, and D. Mesbah. 1996. Agricultural export booms and the rural poor in Chile, Guatemala, and Paraguay. Latin American Research Review 31:33-65.

Cartes, J. L. 2003. Brief history of conservation in the Interior Atlantic Forest. Pages 269-287 in C. Galindo-Leal and I. de Gusmao Camara, editors. The Atlantic Forest of South America: biodiversity status, threats, and outlook. Island Press, Washington, D.C., USA

Cavender-Bares, J., S. Polasky, E. King, and P. Balvanera. 2015. A sustainability framework for assessing trade-offs in ecosystem services. Ecology and Society 20(1): 17. http://dx.doi.org/10.5751/ ES-06917-200117

Chiarello, A. G. 1999. Effects of fragmentation of the Atlantic forest on mammal communities in south-eastern Brazil. 
Biological Conservation 89(1):71-82. http://dx.doi.org/10.1016/ S0006-3207(98)00130-X

Cockle, K. L., M. L. Leonard, and A. A. Bodrati. 2005. Presence and abundance of birds in an Atlantic forest reserve and adjacent plantation of shade-grown yerba mate in Paraguay. Biodiversity and Conservation 14(13):3265-3288. http://dx.doi.org/10.1007/ $\underline{\text { s10531-004-0446-0 }}$

Cossalter, C., and C. Pye-Smith. 2003. Fast-wood forestry: myths and realities. Center for International Forestry Research (CIFOR), Jakarta, Indonesia.

Costanza, R., R. d'Arge, R. de Groot, S. Farber, M. Grasso, B. Hannon, K. Limburg, S. Naeem, R.V. O'Neill, J. Paruelo, R.G. Raskin, P. Sutton, and M. van den Belt. 1997. The value of the world's ecosystem services and natural capital. Nature 387:253260. http://dx.doi.org/10.1038/387253a0

Couto, L. and F. Dube. 2001. The status and practice of forestry in Brazil at the beginning of the $21^{\text {st }}$ century: a review. The Forestry Chronicle 77(5):817-830. http://dx.doi.org/10.5558/tfc77817-5

Cubbage, F., S. Koesbandana, P. Mac Donagh, R. Rubilar, G. Balmelli, V. M. Olmos, R. De La Torre, M. Murara, V. A. Hoeflich, H. Kotze, R. Gonzalez, O. Carrero, G. Frey, T. Adams, J. Turner, R. Lord, J. Huang, C. MacIntyre, K. McGinley, R. Abt, and R. Phillips. 2010. Global timber investments, wood costs, regulation, and risk. Biomass and Bioenergy 34():1667-1678. http://dx.doi.org/10.1016/j.biombioe.2010.05.008

Cubbage, F., P. Mac Donagh, J. Sawinski, Jr., R. Rubilar, P. Donoso, A. Ferreira, G. Ferreira, G. Balmelli, J. Siry, M. N. Baez, and J. Alvarez. 2007. Timber investment returns for selected plantations and native forests in South America and the southern United States. New Forests 33(3):237-255. http://dx.doi. org/10.1007/s11056-006-9025-4

Ditt, E. H., S. Mourato, J. Ghazoul, and J. Knight. 2010. Forest conversion and provision of ecosystem services in the Brazilian Atlantic Forest. Land Degradation and Development 21(6):591603. http://dx.doi.org/10.1002/ldr.1010

Doughty, R. W. 2000. The eucalyptus: a natural and commercial history of the gum tree. Johns Hopkins University Press, Baltimore, Maryland, USA.

Elgert, L. 2012. Can 'responsible soy' production justify the concentration of land in Paraguay? A critical analysis of five claims about environmental, economic, and social sustainability. Global Land Grabbing II, 17-19 October 2012, Land Deals Politics Initiative, Cornell University, Ithaca, New York, USA.

Ellis, F. 1998. Household strategies and rural livelihood diversification. The Journal of Development Studies 35(1):1-38. http://dx.doi.org/10.1080/00220389808422553

Evans, P. T. 1998. Designing agroforestry innovations to increase their adoptability: a case study from Paraguay. Journal of Rural Studies 4(1):45-55. http://dx.doi.org/10.1016/0743-0167(88) 90078-2

Farley, J. and R. Costanza. 2010. Payments for ecosystem services: from local to global. Ecological Economics 69(11):2060-2068. http://dx.doi.org/10.1016/j.ecolecon.2010.06.010
Fearnside, P. M., and R. I. Barbosa. 1998. Soil carbon changes from conversion of forest to pasture in Brazilian Amazonia. Forest Ecology and Management 108(1-2):147-166. http://dx.doi. org/10.1016/S0378-1127(98)00222-9

Fialho, R. C. and Y. L. Zinn. 2012. Changes in soil organic carbon under eucalyptus plantations in Brazil: a comparative analysis. Land Degradation and Development 25(5):428-437. http://dx.doi. org/10.1002/1dr.2158

Finnis, E., C. Benitez, E. F. Candia Romero, and M. J. Aparicio Meza. 2012. Changes to agricultural decision making and food procurement strategies in rural Paraguay. Latin American Research Review 47(2):180-190. http://dx.doi.org/10.1353/ $\underline{\text { lar.2012.0023 }}$

Food and Agriculture Organization of the United Nations (FAO). 2004. Estrategia para el desarrollo forestal en el Cono Sur, Volume III: Paraguay y Uruguay. Investment Center, Cooperative Program of the FAO and World Bank, Rome, Italy.

Food and Agriculture Organization of the United Nations (FAO). 2011. State of the world's forests. FAO, Rome, Italy.

Fragano, F., and R. Clay. 2003. Biodiversity status of the interior Atlantic Forest of Paraguay. Pages 288-309 in C. Galindo-Leal and I. de Gusmao Camara, editors. The Atlantic Forest of South America: biodiversity status, threats, and outlook. Island, Washington, D.C., USA.

Galeano, L.A. 2010. Potential and future of Paraguayan family farming. Pages 101-122 in A. Berry, editor. Losing ground in the employment challenge: the case of Paraguay. Transaction, New Brunswick, New Jersey, USA.

Gattini, J. 2011. Nuevos aportes para las políticas públicas en Paraguay: competitividad de la agricultura familiar en Paraguay. Centro de Análisis y Difusión de la Economía Paraguaya, Asunción, Paraguay.

General Directorate for Statistics, Surveys and Census (Dirección General de Estadística, Encuestas, y Censos; DGEEC). 2012. Encuesta permanente de hogares 2011: distribución de ingresos y pobreza. DGEEC, Fernando de la Mora, Paraguay.

Geist, H. J., and E. F. Lambin. 2002. Proximate causes underlying driving forces of tropical deforestation. Bioscience 52(2):143-150. http://dx.doi.org/10.1641/0006-3568(2002)052[0143:PCAUDF]2.0. $\underline{\mathrm{CO} ; 2}$

Goerck, J. M. 1997. Patterns of rarity in birds of the Atlantic Forest in Brazil. Conservation Biology 11(1):112-118. http://dx. doi.org/10.1046/j.1523-1739.1997.95314.X

Green, R. E., S. E. Cornell, J. P. W. Scharlemann, and A. Balmford. 2005. Farming and the fate of wild nature. Science 307 (5709):550-555. http://dx.doi.org/10.1126/science.1106049

Grossman, J. J. 2012. A case study of smallholder eucalyptus plantation silviculture in eastern Paraguay. Forestry Chronicle 88 (5):528-534. http://dx.doi.org/10.5558/tfc2012-101

Grossman, J. J. 2014. Eucalypts in agroforestry, reforestation, and smallholders' conceptions of "nativeness": a multiple case study of plantation owners in eastern Paraguay. Small-scale Forestry 1 August, 2014. http://dx.doi.org/10.1007/s11842-014-9272-8 
Guo, L. B., and R. M. Gifford. 2002. Soil carbon stocks and land use change: a meta analysis. Global Change Biology 8(4):345-360. http://dx.doi.org/10.1046/j.1354-1013.2002.00486.x

Haberl, H., K. H. Erb, F. Krausmann, V. Gaube, A. Bondeau, C. Plutzar, S. Gingrich, W. Lucht, and M. Fischer-Kowalski. 2007. Quantifying and mapping the human appropriation of net primary production in earth's terrestrial ecosystems. Proceedings of the National Academy of Sciences 104(3):12942-12947. http:// dx.doi.org/10.1073/pnas.0704243104

Haight, R. G. 1995. Comparing extinction risk and economic cost in wildlife conservation planning. Ecological Applications 5 (3):767-775. http://dx.doi.org/10.2307/1941984

Hamilton, J. V., and J. C. Bliss. 1998. Agroforestry extension in Paraguay: the participants' perspective. Journal of Forestry 96:1519.

Hansen, M. C., and R. S. DeFries. 2004. Detecting long-term global forest change using continuous fields of tree-cover maps from 8-km advanced very high resolution radiometer (AVHRR) data for the years 1982-99. Ecosystems 7(7):695-716. http://dx. doi.org/10.1007/s10021-004-0243-3

Harvey, C. A., A. Medina, D. M. Sánchez, S. Vílchez, B. Hernández, J. C. Saenz, J. M. Maes, F. Casanoves, and F. L. Sinclair. 2006. Patterns of animal diversity in different forms of tree cover in agricultural landscapes. Ecological Applications 16 (5):1986-1999. http://dx.doi.org/10.1890/1051-0761(2006)016[1986: POADID]2.0.CO:2

Hetherington, K. 2009. Privatizing the private in rural Paraguay: precarious lots and the materiality of rights. American Ethnologist 36(2):224-241. http://dx.doi.org/10.1111/j.1548-1425.2009.01132. $\underline{\mathrm{x}}$

Hirschi, C., A. Widmer, S. Briner, and R. Huber. 2013. Combining policy network and model-based scenario analyses: an assessment of future ecosystem goods and services in Swiss mountain regions. Ecology and Society 18(2): 42. http://dx.doi.org/10.5751/ ES-05480-180242

Hooper, D. U., F. S. Chapin, III, J. J. Ewel, A. Hector, P. Inchausti, S. Lavorel, J. H. Lawton, D. M. Lodge, M. Loreau, S. Naeem, B. Schmid, H. Setala, A. J. Symstad, J. Vandermeer, and D. A. Wardle. 2005. Effects of biodiversity on ecosystem functioning: a consensus of current knowledge. Ecological Monographs 75 (1):3-35. http://dx.doi.org/10.1890/04-0922

Hosier, R. H. 1989. The economics of smallholder agroforestry: two case studies. World Development 17(11):1827-1839. http://dx. doi.org/10.1016/0305-750X(89)90202-7

Huang, C., S. Kim, A. Alstatt, J. R. G. Townshend, P. Davis, K. Song, C. J. Tucker, O. Rodas, A. Yanosky, R. Clay, and J. Musinsky. 2007. Rapid loss of Paraguay's Atlantic forest and the status of protected areas: a Landsat assessment. Remote Sensing of Environment 106(4):460-466. http://dx.doi.org/10.1016/j. $\underline{\text { rse.2006.09.016 }}$

Huang, C., S. Kim, K. Song, J. R. G. Townshend, P. Davis, A. Alstatt, O. Rodas, A. Yanosky, R. Clay, C. J. Tucker, and J. Musinsky. 2009. Assessment of Paraguay's forest cover change using Landsat observations. Global and Planetary Change 67 (1):1-12. http://dx.doi.org/10.1016/j.gloplacha.2008.12.009
Hussain, A. M. T. and J. Tschirhart. 2013. Economic/ecological trade-offs among ecosystem services in biodiversity conservation. Ecological Economics 93:116-127. http://dx.doi.org/10.1016/j. ecolecon.2013.04.013

International Assessment of Agricultural Knowledge, Science, and Technology for Development (IAASTD). 2009. IAASTD: synthesis report with executive summary. Island, Washington, D. C., USA.

Japanese International Cooperation Association (JICA). 2002. Country profile on environment: Paraguay. Planning and Evaluation Department, JICA, Tokyo, Japan.

Knowler, D., and B. Bradshaw. 2007. Farmers' adoption of conservation agriculture: a review and synthesis of recent research. Food Policy 32(1):25-48. http://dx.doi.org/10.1016/j. foodpol.2006.01.003

Lambin, E. F., B. L. Turner, H. J. Geist, S. B. Agbola, A. Angelson, J. W.Bruce, O. T. Coomes, R. Dirzo, G. Fisher, C. Folke, P. S. George, K. Homewood, J. Imbernon, R. Leemans, X. Li, E. F. Moran, M. Mortimore, P. S. Ramakrishnan, J. F. Rihards, H. Skanes, W. Steffen, G. D. Stone, U. Svedin, T. A. Veldkamp, C. Vogel, and J. Xu. 2001. The causes of land use and land-cover change: moving beyond the myths. Global Environmental Change 11(4):261-269. http://dx.doi.org/10.1016/S0959-3780(01)00007-3

Lester, S. E., C. Costello, B. S. Halpern, S. D. Gaines, C. White, and J. A. Barth. 2013. Evaluating trade-offs among ecosystem services to inform marine spatial planning. Marine Policy 38:80 89. http://dx.doi.org/10.1016/j.marpol.2012.05.022

Lichtenstein, M. E., and C. A. Montgomery. 2003. Biodiversity and timber in the Coast Range of Oregon: inside the production possibility frontier. Land Economics 79(1):56-73. http://dx.doi. org $/ 10.2307 / 3147105$

MacArthur, R. H. 1965. Patterns of species diversity. Biological Reviews 40(4):510-533. http://dx.doi.org/10.1111/j.1469-185X.1965. tb00815.x

Mace, G. M., K. Norris, and A. H. Fitter. 2012. Biodiversity and ecosystem services: a multilayered relationship. Trends in Ecology and Evolution 27(1):19-26. http://dx.doi.org/10.1016/j.tree.2011.08.006

Macedo, A. M., and J. L. Cartes. 2003. Socioeconomic drivers in the interior Atlantic Forest. Pages 310-324 in C. Galindo-Leal and I. de Gusmao Camara, editors. The Atlantic Forest of South America: biodiversity status, threats, and outlook. Island, Washington, D.C., USA.

Marsden, S. J., M. Whiffin, and M. Galetti. 2001. Bird diversity and abundance in forest fragments and eucalyptus plantations around an Atlantic Forest reserve, Brazil. Biodiversity and Conservation 10(5):737-751. http://dx.doi.org/10.1023/A:1016669118956

Millennium Ecosystem Assessment (MEA). 2005. Ecosystems and human well-being: synthesis. Island, Washington, D.C., USA.

Ministry of Agriculture and Livestock (MAG). 2008. Sistemas sostenibles de producción para los principales cultivos agrícolas, hortícolas, forestales y agroforestales de la Región Centro del Paraguay. Sustainable Natural Resources Management Program (Proyecto de Manejo Sostenible de Recursos Naturales), MAG / German Technical Cooperation Agency (Deutsche Gesellschaft für Technische Zusammenarbeit; GTZ), Asunción, Paraguay. 
Ministry of Agriculture and Livestock. 2009. Censo agropecuario nacional 2008: Volumen I. MAG, San Lorenzo, Paraguay.

Ministry of Agriculture and Livestock. 2010. Síntesis de la producción y el comercio pecuario del Paraguay. MAG, San Lorenzo, Paraguay.

Ministry of Agriculture and Livestock. 2011. Manejo forestal y agricultura de conservación: experiencias de pequeños productores en la Región Oriental de Paraguay. MAG / GTZ, Asunción, Paraguay.

Moilanen, A., B. J. Anderson, F. Eigenbrod, A. Henemeyer, D. B. Roy, S. Gillings, P. R. Armsworth, K. J. Gaston, and C. D. Thomas. 2011. Balancing alternative land uses in conservation prioritization. Ecological Applications 21(5):1419-1426. http:// dx.doi.org/10.1890/10-1865.1

Molinas, J. R. 1998. The impact of inequality, gender, external assistance and social capital on local-level cooperation. World Development 26(5):413-431. http://dx.doi.org/10.1016/S0305-750X (97)10066-3

Montgomery, C. A., G. M. Brown, Jr., and D. M. Adams. 1994. The marginal cost of species preservation: the northern spotted owl. Journal of Environmental Economics and Management 26 (2):111-128. http://dx.doi.org/10.1006/jeem.1994.1007

Montgomery, C. A., R. A. Pollak, K. Freemark, and D. White. 1999. Pricing biodiversity. Journal of Environmental Economics and Management 38(1):1-19. http://dx.doi.org/10.1006/jeem.1999.1073

Moreira, A., and N. K. Fageria. 2011. Changes in soil properties under two different management systems in the western Amazon. Communications in Soil Science and Plant Analysis 42(21):26662681. http://dx.doi.org/10.1080/00103624.2011.614041

Myers, N., R. A. Mittermeler, C. G. Mittermeler, G. A. B. da Fonseca, and J. Kent. 2000. Biodiversity hotspots for conservation priorities. Nature 403:853-858. http://dx.doi.org/10.1038/35002501

Naidoo, R., and W. L. Adamowicz. 2006. Modeling opportunity costs of conservation in transitional landscapes. Conservation Biology 20(2):490-500.http://dx.doi.org/10.1111/j.1523-1739.2006.00304. $\underline{\mathrm{X}}$

Naidoo, R., and T. H. Ricketts. 2006. Mapping the economic costs and benefits of conservation. Public Library of Science Biology 4 (11):e360. http://dx.doi.org/10.1371/journal.pbio.0040360

Nelson, E., G. Mendoza, J. Regetz, S.Polasky, H. Trails, R. Cameron, K. M. Chan, G. C. Daily, J. Goldstein, P. M. Kareiva, E. Lonsdorf, R. Naidoo, T. H. Ricketts, and R. Shaw. 2009. Modeling multiple ecosystem services, biodiversity conservation, commodity production, and trade-offs at landscape scales. Frontiers in Ecology and the Environment 7(1):4-11. http://dx.doi. org/10.1890/080023

Paraguay Rural Association (Asociación Rural del Paraguay; ARP). 2010. Manual compendio de la ganadería Paraguaya. ARP, Mariano Roque Alonso, Paraguay.

Pereira, J. M., R. M. Tarré, R. Macedo, C. de Paula Rezende, B. J. R. Alves, S. Urquiaga, and R. M. Boddey. 2009. Productivity of Brachiaria humidicola pastures in the Atlantic Forest region of Brazil as affected by stocking rate and the presence of a forage legume. Nutrient Cycling in Agroecosystems 83(2):179-196. http:// dx.doi.org/10.1007/s10705-008-9206-y

Perfecto, I., and J. Vandermeer. 2010. The agroecological matrix as alternative to the land-sparing/agriculture intensification model. PNAS 107(13):5786-5791. http://dx.doi.org/10.1073/ pnas.0905455107

Phalan, B., A. Balmford, R. E. Green, and J. P. W. Scharlemann. 2011. Minimising the harm to biodiversity of producing more food. Food Policy 36(1):S62-S71. http://dx.doi.org/10.1016/j. foodpol.2010.11.008

Plaza Pinto, M., J. A. Felizola Diniz-Filho, L. M. Bini, D. Blamires, and T. F. L. V. B. Rangel. 2008. Biodiversity surrogate groups and conservation priority areas: birds of the Brazilian Cerrado. Diversity and Distributions 14(1):78-86. http://dx.doi. org/10.1111/j.1472-4642.2007.00421.x

Polasky, S., E. Nelson, E. Lonsdorf, P. Fackler, and A. Starfield. 2005. Conserving species in a working landscape: land use with biological and economic objectives. Ecological Applications 15:1387-1401. http://dx.doi.org/10.1890/03-5423

Polasky, S., E. Nelson, J. Camm, B. Csuti, P. Fackler, E. Lonsdorf, C. Montgomery, D. White, J. Arthur, B. Garber-Yonts, R. Haight, J. Kagan, A. Starfield, and C. Tobalske. 2008. Where to put things? Spatial land management to sustain biodiversity and economic returns. Biological Conservation 141(6):1505-1524. http://dx.doi. org/10.1016/j.biocon.2008.03.022

Polasky, S., K. Johnson, B. Keeler, K. Kovacs, E. Nelson, D. Pennington, A. J. Plantinga, and J. Whithey. 2012. Are investments to promote biodiversity conservation and ecosystem services aligned? Oxford Review of Economic Policy 28(1):139163. http://dx.doi.org/10.1093/oxrep/grs011

Quintana, J., and S. Morse. 2005. Social interactions and resource ownership in two private protected areas of Paraguay. Journal of Environmental Management 77(1):64-78. http://dx.doi.org/10.1016/ j.jenvman.2005.02.014

Red Rural. 2012. Estudio de la canasta familiar alimenticia en poblaciones pobres rurales y urbanos. Red Rural de Organizaciones Privadas de Desarrollo, Asunción, Paraguay.

Rey Benayas, J. M., A. C. Newton, A. Diaz, and J. M. Bullock. 2009. Enhancement of biodiversity and ecosystem services by ecological restoration: a meta-analysis. Science 325(5994):11211124. http://dx.doi.org/10.1126/science. 1172460

Rizvi, S. J. H., M. Tahir, V. Rizvi, R. K. Kohli, and A. Ansari. 2009. Allelopathic interactions in agroforestry systems. Critical Reviews in Plant Sciences 18(62):773-796. http://dx.doi. org/10.1080/07352689991309487

Rômulo, R., J. E. Simon, and G. T. de Mattos. 2003. Bird extinctions in Atlantic Forest fragments of the Viçosa region, southeastern Brazil. Conservation Biology 17(6):1827-1839. http://dx.doi.org/10.1111/j.1523-1739.2003.00377.x

Sandker, M., M. Ruiz-Perez, and B. M. Campbell. 2012. Tradeoffs between biodiversity conservation and economic development in five tropical forest landscapes. Environmental Management 50(4):633-644. http://dx.doi.org/10.1007/s00267-012-9888-4 
Shiferaw, B. A., J. Okello, and R. V. Reddy. 2009. Adoption and adaptation of natural resource management innovations in smallholder agriculture: reflections on key lessons and best practices. Environment, Development, and Sustainability 11 (3):601-619. http://dx.doi.org/10.1007/s10668-007-9132-1

Shiva, V., and J. Bandyopadhyay. 1987. Ecological audit of eucalyptus cultivation. Research Foundation for Science and Ecology, Dehra Dun, India.

Silvano, R. A. M., S. Udvardy, M. Ceroni, and J. Farley. 2005. An ecological integrity assessment of a Brazilian Atlantic Forest watershed based on surveys of stream health and local farmers' perceptions: implications for management. Ecological Economics 53(3):369-385. http://dx.doi.org/10.1016/j.ecolecon.2004.12.003

Tabarelli, M., A. V. Aguiar, M. C. Ribeiro, J. P. Metzger, and C. A. Peres. 2010. Prospects for biodiversity in the Atlantic Forest: lessons from aging human-modified landscapes. Biological Conservation 143(10):2328-2340. http://dx.doi.org/10.1016/j. biocon.2010.02.005

Terborgh, J. W., and J. Faaborg. 1980. Saturation of bird communities in the West Indies. The American Naturalist 116 (2):178-195. http://dx.doi.org/10.1086/283621

Tscharntke, T., Y. Clough, T. C. Wagner, L. Jackson, I. Motzke, I. Perfecto, J. Vandermeer, and A. Whitbread. 2012. Global food security, biodiversity conservation and the future of agricultural intensification. Biological Conservation 151(1):53-59. http://dx. doi.org/10.1016/j.biocon.2012.01.068

Turner, C. B. 1998. The world system and cooperative development in rural Paraguay. Human Organization 57:430-436.

Uezu, A., D. D. Beyer, and J. P. Metzger. 2008. Can agroforest woodlots work as stepping stones for birds in the Atlantic Forest region? Biodiversity and Conservation 17(8):1907-1922. http://dx. doi.org/10.1007/s10531-008-9329-0

United Nations Statistics Division. 2013. World statistics pocketbook: Paraguay. United Nations (UN), New York, New York, USA. [online] URL: https://data.un.org/CountryProfile. aspx? crName $=$ PARAGUAY

van Berkel, D. B., and P. H. Verburg. 2014. Spatial quantification and valuation of cultural ecosystem services in an agricultural landscape. Ecological Indicators 37:163-174. http://dx.doi. org/10.1016/j.ecolind.2012.06.025

Vázquez-León, M. 2010. Free markets and fair trade, collective livelihood struggles, and the cooperative model: two case studies from Paraguay. Latin American Perspectives 37:53-73. http://dx. doi.org/10.1177/0094582X10382099

World Bank (WB). 2014. World Bank data: Paraguay. World Bank, Washington, D.C., USA. [online] URL: http://data. worldbank.org/country/paraguay

Weisskoff, R. 1992. The Paraguayan agro-export model of development. World Development 20(10):1531-1540. http://dx. doi.org/10.1016/0305-750X(92)90072-4
Wolters, V., J. Bengtsson, and A. S. Zaitsev. 2006. Relationship among the species richness of different taxa. Ecology 87(8):18861895. http://dx.doi.org/10.1890/0012-9658(2006)87[1886:RATSRO] 2.0. $\mathrm{CO} ; 2$

Yanosky, A., and E. Cabera. 2003. Conservation capacity in the interior Atlantic Forest of Paraguay. Pages 328-356 in C. Galindo-Leal and I. de Gusmao Camara, editors. The Atlantic Forest of South America: biodiversity status, threats, and outlook. Island, Washington, D.C., USA.

Yin, R. K. 2003. Case study research. Sage, Thousand Oaks, California, USA.

Zurita, G. A., N. Rey, D. M. Varela, M. Villagra, and M. I. Bellocq. 2006. Conversion of the Atlantic Forest into native and exotic tree plantations: effects on bird communities from the local and regional perspectives. Forest Ecology and Management 235(13):164-173. http://dx.doi.org/10.1016/j.foreco.2006.08.009 